\title{
Can You Question Science in a Pandemic? Provocations on the History of Health land Food) in Japan After COVID
}

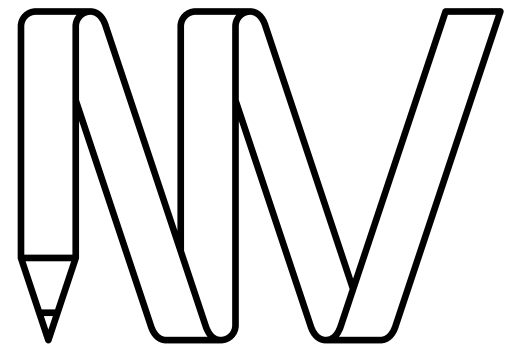

NEW

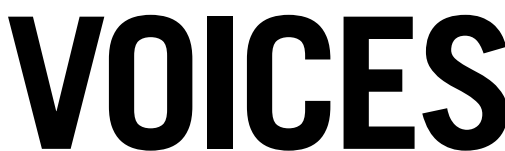
IN JAPANESE JOSHUA SCHLACHET

University of Arizona STUDIES

\section{ABSTRACT}

This article, through a series of provocations and anecdotes from my research into dietary health in early modern Japan (1600-1868), makes the case for transhistorical thinking as a productive analytical mode, allowing the past to speak to present concerns in creative and unexpected ways. As this volume seeks a fresh approach to Japanese Studies post-pandemic, addressing this tension between past and present, I argue, offers a productive way to turn the challenges of COVID-19 into opportunities for greater impact and interconnection. Now, however, is a bad time to question science. Vaccine hesitancy, resistance to mask mandates, and the overall politicization of commonsense health guidelines among a substantial plurality of the population indicate a sustained mistrust of health science expertise precisely when belief and compliance would do the most medical and social good. Doing the history of health in Japan through a transhistorical lens, I argue, exposes how a set of social divisions and challenges that may appear through a presentist lens to be as novel as the virus itself, and tied inextricably to the demands and paradoxes of modern state-based public health regimes, are in fact variants of issues that have been faced in dramatically different historical circumstances. This article follows these themes through three broad provocations that resonate between health's past and present, drawn from the nineteenth-century history of diet and nutrition in Japan: skepticism of doctors and a critique of medical expertise; prioritising preventative versus retroactive care; and balancing health with opening the economy.

\section{KEYWORDS}

contemporary; COVID-19; Edo period; health; history; Japanese studies; nutrition; nourishing life; print media; transnationalism

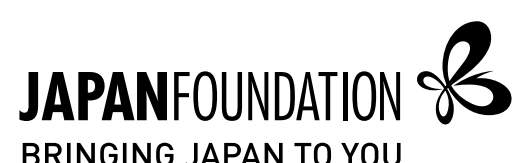

To link to this article: https://doi.org/10.21159/nvjs.12.03

\section{ISSN 2205-3166}

New Voices in Japanese Studies is an interdisciplinary, peer-reviewed journal showcasing the work of emerging scholars with ties to Australia or New Zealand and research interests in Japan.

All articles can be downloaded free at newvoices.org.au

(C) The Japan Foundation, Sydney and Joshua Schlachet, 2021

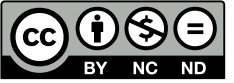

This work is licensed under a Creative Commons Attribution-NonCommercialNoDerivatives 4.0 International License. 
$\mathrm{N}^{\infty}$ ow is a bad time to question science. As the COVID-19 pandemic rages unabated, vaccine denialism and failure to comply with public health rules stem, in part, from a politicised skepticism over the validity of scientific findings. Similar concerns drive the repudiation of climate change, which has gripped a distrustful public and conservative political coalition in the face of overwhelming scientific consensus. In the United States most acutely, this crisis of trust in expertise reveals the fragility of public belief in scienceparticularly health science-and the complex social structures by which it is formed, maintained and increasingly undermined.

The COVID-19 pandemic has posed new and unanticipated challenges for Japanese Studies, not only in the accessibility of archives but also in the basic formation of our research questions. Archives and national borders will reopen, in time, and current disruptions to the rhythms of life and work, both monumental and temporary, will one day feel like history themselves. For now, as we reflect on the future of Japanese Studies, and of bridging our work across global borders, many of us with the privilege to do so remain stationary in our homes. Pandemic lockdown, in this sense, offers an ideal moment to remind ourselves that there are all kinds of borders to cross in research besides just spatial and national ones.

Yet for those of us in the history of health, and in my own research on the social composition of diet in Japan, the intertwined medical-economicsocietal response to the novel coronavirus will have lasting implications that force us to confront the presentness of research that previously resided safely in the past, supposedly insulated by layers of chronology and thus alterity. The contentious nature of health guidance, especially when it involves social and economic trade-offs, compels us to search for precedents, to plumb the past for answers, to seek solace that our questions are not new.

As this volume, and the symposium from which it emerged, seek a fresh, interdisciplinary and border-crossing approach to Japanese Studies postpandemic, addressing this tension between past and present, I argue, offers a productive way to turn the challenges of COVID-19 into opportunities for greater impact and interconnection. This article, through a series of provocations and anecdotes from my research into dietary health in early modern Japan (1600-1868), makes the case for transhistorical thinking as a productive analytical mode, allowing the past to speak to present concerns in creative and unexpected ways. ${ }^{1}$ It also represents an attempt to work through what I understand to be a new and existential question raised by the pandemic: what does one do when one's scholarly arguments about the past arrive in a place counter to deeply held beliefs about right behavior in the present, and specifically about believing in and following best practices for public health set out by doctors and scientists? Can an otherwise wellintentioned humanistic study that questions the objectivity of science 
risk undermining our own convictions about the collective social value of biomedical knowledge at a time when it is already under fire for very different reasons? Put more succinctly, can you question science during a pandemic?

My field of research pursues this question by tracing the emergence of dietary common knowledge in late-Edo and early-Meiji Japan, and by investigating how ideas of eating right became both a popular phenomenon and a matter of grave concern among trained medical experts and amateur culinary enthusiasts alike. Beginning in the eighteenth century, Japan witnessed an unprecedented explosion of popular interest in dietary advice, compiled in commercially printed manuals, pamphlets and guides to household knowhow, dedicated to practices for promoting wellbeing known collectively as 'nourishing life' (養生). Beyond simply informing people how to eat right, such guidance expanded the concept of a well-nourished body to include economic productivity, status hierarchy and moral cultivation. Dietary health, as such, was never value-free, nor was it reducible to an objective, scientific relationship between nutrients and their physiological outcomes in the body. Instead, guidance on eating right conveyed priorities about how well-nourished bodies were meant to act in the world, whether as agricultural workers, samurai bureaucrats, or merchant consumers.

By questioning science, I refer to two interrelated ideas. The first is science as a historical problem of hegemonic discourse that entered Japan during the public hygiene campaigns of the early Meiji period and, in doing so, overshadowed a broad-based popular culture of preventative health that came before, and in modified ways, lived on after. ${ }^{2}$ This historical process, to which I will return below, carried a strong semi-colonial connotation, both adopted based on Western precedents and, soon after, wielded by the Japanese imperial state in its own colonies. ${ }^{3}$ The second idea is of science as a methodological quandary: is it the most appropriate and relevant framework through which to understand the relationship between food and health in Japan's early modern context? Among the goals of my research into the history of dietary health in Japan has been to critique scientific nutrition through a humanistic and historical lens, to interrogate subjects of purported objective truth often reserved for those who study scientific fact. My work on the social dimensions of dietary health in Japan emerged, in part, from U.S. food historian Charlotte Biltekoff's call to "consider nutrition itself-not just its practice but its content-as a product of history" (see Biltekoff 2013, 5-7). Even without this scaffolding of medicalised public health knowledge, Japan's past shared many concerns with today's pandemic-stricken world.

Yet the COVID-19 pandemic and the uneven variety of human responses to it puts a research goal of critiquing historical understandings of science at odds with my own normative response in the present that presupposes a welcomed hegemony of scientific knowledge: you should wear a mask, you should get a vaccine, scientific consensus exists whether you believe in 
it or not. Vaccine hesitancy, resistance to mask mandates, and the overall politicisation of commonsense health guidelines among a substantial plurality of the population indicate a sustained mistrust of health science expertise precisely when belief and compliance would do the most medical and social good.

Here in the United States, faith in what used to be agreed-upon science appears shaken by recognition of the deep social consequences of our actions or inactions. According to survey data from the U.S. Census Bureau, as of February 2021, nearly 25\% of unvaccinated adults "probably or definitely will not" receive a COVID-19 vaccine, and only half will "definitely" get it. The top two reasons for hesitancy, at $50 \%$ of respondents or more each, are "Concerned about possible side effects" and "Plan to wait and see if it is safe". Further down the list are "Don't trust COVID-19 vaccines" (approx. $20 \%)$, "Don't trust the government" (18.5\%), and other reasons that similarly suggest a distrust of expert opinion (File and Mohanty 2021). According to a meta-analysis published in the New England Journal of Medicine, only 58\% of Americans trust health professionals as a source of information on the coronavirus vaccine, and no medical or political institution scored above $50 \%$ trustworthiness (Steelfisher et al. 2021, 1484-85). The pandemic has birthed a crisis of confidence, unprecedented in living memory, that threatens to subvert public health responses to it.

To be limited by living memory in our search for a post-pandemic Japanese Studies, or a way out of divisive mistrust of science, however, would be a missed opportunity to think with history towards a deeper context for the socio-political resonances of the coronavirus. In pursuing such a transhistorical approach, I do not mean that we must fall back on a naive history-repeats-itself-ism, nor can we simply look to the past for ready-made answers to today's problems. I aim instead for a recognition of resonances and a-perhaps cathartic-acknowledgement that inhabitants of the past grappled with similar questions. Doing the history of health in Japan in this way exposes how a set of social divisions and challenges that may appear through a presentist lens to be as novel as the virus itself, and tied inextricably to the demands and paradoxes of modern state-based public health regimes, are in fact variants of issues that have been faced, and at least temporarily resolved, in dramatically different historical circumstances. In this sense, looking to our interlocutors in the past can reveal that their concerns about health speak to our own today, even if they sometimes arrived at very different conclusions.

The remaining pages sketch three provocations, drawn from the nineteenthcentury history of diet and nutrition in Japan, each meant to arouse a conversation on resonances between health's past and present: skepticism of doctors and a critique of medical expertise; prioritising preventative versus retroactive care; and balancing health with opening the economy. Using the history of nutrition to think through present concerns over vaccination may seem, at first glance, like an apples-to-oranges comparison, especially given Japan's own history with vaccination campaigns in the nineteenth century, 
smallpox chief among them. ${ }^{4}$ (Similarly, in the American news media, the 1918 Spanish flu pandemic has been the historical comparison of choice.) My goal, however, is to highlight the diverse and varied approaches to healing and treatment employed in the past that may not conform to current biomedical definitions of medicine, in order to offer a historical perspective on the present resistance to COVID-19 measures that has emerged in the U.S. and other contexts.

The history of diet and health in Japan, though it may not provide ready answers to the problems of COVID-19, does reveal how relevant our questions prompted by the pandemic have been before. This is exactly the messy process of looking across borders, not just national but chronological, methodological and ideological. With this in mind, I contend that you can question science during a pandemic, from an academic perspective, even when unfounded skepticism otherwise abounds. To do so, however, requires us to acknowledge that belief in expert medical knowledge and its promise of concrete outcomes for individual bodies is only one of many historical ways of understanding health.

\section{PROVOCATION ONE: SKEPTICISM OF DOCTORS, FOR BETTER OR WORSE, IS NOTHING NEW}

In the midst of the COVID-19 pandemic, skepticism over the qualifications of trained medical professionals charged with our collective care has spawned anew among a polarised public, stoked by the rhetoric of political officials up to and including the former President of the United States. "People are tired of hearing [Dr. Anthony] Fauci and these idiots," Donald Trump asserted on a 2019 campaign phone call, "all these idiots who got it wrong" (Haberman and Crowley 2020). To greet an unimpeachable medical career with suspicion and antagonism, it would seem, is a result of adjudicating debates over whom to trust within a contentious public-as opposed to professional or institutional-domain. Yet to isolate such skepticism as a byproduct of the state of contemporary political disputes obscures longstanding debates about medical qualifications that reemerge intensified in times of crisis. In early modern Japan, in lieu of any unified accrediting institution, the domain of popular print and public information was precisely where such debates over medical authority took place. Whereas COVID-19 disinformation and denialism has thus far served to erode public faith in commonsense public health measures, a generally skeptical outlook on doctors perpetuated by Edo-period print media called into question not necessarily the content of medical advice itself but those who dispensed it, painting them as deserving of doubt and disbelief.

In early-nineteenth century Japan, heightened anxiety over whom to trust with one's health was a symptom of the increasingly intertwined-and increasingly ambiguous-relationship between information, particularly in print, and authority once dietary commentary began to flood the popular 
publishing market (Takizawa 2003; 1993). In particular, I refer to 'nourishing life texts', a genre of guides or manuals that both fed off and shaped growing public interest in health and longevity, and which were produced by publishers and commentators with varied levels of health-related expertise. As purveyors of information on health proliferated, so too did distrust, amateurism and misinformation that raised questions about the qualifications of medical experts and the value of their professional knowledge. Unlike the tomes of elite knowledge that held the secrets to medical practice in Japan before the Tokugawa period, the simple, vernacular guidebooks that circulated during the nineteenth century were often texts by amateurs telling other amateurs how to choose from among professionals. The distrust toward medicine and its practitioners that some nourishing life texts encouraged was a result of their authors' orientation toward food and lifestyle as prevention of illness. ${ }^{5}$

Authors of dietary health advice in early modern Japan, particularly those without medical backgrounds, encouraged readers to view doctors with a dose of skepticism and suspicion, sometimes bordering on outright hostility. Guidebooks were preoccupied with the quality and motivations of purveyors of bodily care. Many nourishing life manuals, including the immensely popular Yōjōkun [養生訓; 1713] by the celebrated natural philosopher Ekiken Kaibara [貝原 益軒; 1630-1714], contain sections on 'choosing a doctor' ( 醫撰), which explain how to distinguish a competent professional from an untrained quack who is just out to collect money (Kaibara 1972 [1713]). In cases when consulting a doctor was necessary, exercising responsibility over one's own health extended to selecting a doctor who had the patient's best interests in mind (Sakai 2003, 144).

Takeharu Miyake [三宅 建治; dates unknown] was particularly critical of medical practitioners in his Japanese Household Secrets [日本居家秘用; 1806 (1737)]. "In today's world, there are few doctors with clear understanding," he suggested. "Many doctors these days butter you up, show a kind face and tug at your heartstrings" (Miyake 1806 [1737]b, 35). ${ }^{6}$ Most, he claimed, were clouded by the biases of their lineage and advanced through patronage and connections rather than achievement. He compared the doctors of his day unfavorably to those of the past, suggesting that they guessed at diseases and cures, prescribed ineffective medicines and dispensed incorrect advice (37). As a remedy, he argued it was up to the reader to keep physicians honest. "Those who take up medicine as a profession should put their hearts into it and determine the truth," he suggested. "The ill should also put their hearts into the way of medicine. When someone in the household is sick, one should select [the right] doctor and help care for them" (43). ${ }^{7}$ To safeguard against lazy or unethical behavior, patients had to know enough about medicine to be their own advocates, to judge for themselves the quality of care they received.

Even from these limited examples, we can sense a transformation in the practice and popular perception of medicine itself, further complicated by the

5 For more on emergence and rationale of this emerging dietary health movement in early modern Japan, see Schlachet $(2018,105)$.

6 「今乃醫者おほく八諂ふものありて面をや八らかにして人乃心をとり....」All translations mine unless otherwise indicated.

7 「醫を業とする人にて心を用ひ真理をさとるべき事なるべし病家も常に醫乃道に心をよせ病ある時醫を撰ひ看病の助 
fact that the category of doctor in the Tokugawa era was broad, indefinite and only partially comparable to the standards of medical professionalisation in the present. ${ }^{8}$ Because the medical profession crossed the boundaries of the status system and lacked an official certification structure, being a doctor often came with a degree of social mobility, or at least an indeterminate position within the hierarchy (Umihara 2014, 2-5). ${ }^{9}$ Although high-ranking doctors in service of the shogunate or the imperial court tended to come from samurai families or the Buddhist priesthood, if a rural doctor was noticed for his talents, he could be promoted into the service of a prominent family or even the government (Sakai 2003, 46).

The behavior that nourishing life guides interpreted as laziness or dishonesty was likely a product of the economic pressures and uneven training facing physicians without the luxury of official employment. Unlike domainal doctors who often received a stipend for their services, local doctors in towns and villages throughout the archipelago had no such status protection and had to survive on their own talent and effort (Umihara 2014, 2-5). Conversely, expanded access to previously esoteric medical expertise was due, in part, to the proliferation of knowledge on materia medica that flourished from the second half of the eighteenth century, making it difficult to pin down a single, encompassing definition of an Edo-era doctor. As Alessandro Bianchi suggests, because "scholars and intellectuals were no longer the only persons with access", doctors became a subject of criticism from both a skeptical public and a newly ascendant mode of preemptive care $(2014,66)$. Thus, flexibility in the category of 'physician' led to unevenness in the quality of care one might receive, or at least fuelled the perception that not all doctors were deserving of trust or respect.

\section{PROVOCATION TWO: PREVENTION IS BETTER THAN A CURE}

Since early in the pandemic, preventing the spread of COVID-19 using public health interventions-including mask wearing, social distancing, and now vaccinations-has received outsized attention compared with innovations in medicative treatments for patients who have already contracted severe cases of the virus. Though public buy-in in the United States has been mixed at best, the oft-quoted imperative to 'bend the curve,' to prioritise preventative over retroactive care, demonstrates how maintaining health has been mobilised as a strategy to preempt infection. As inhabitants of Edo Japan both experienced and anticipated the outbreak of epidemic diseases, it is clear that the emerging genre of vernacular dietary guidebooks at the time opened a rift between two groups. On the one side were the promoters of food-based deterrence of ill-health, and on the other, the purveyors of medication and curative interventions, who already occupied a less unified or concrete social and professional space than physicians of today. 
Nourishing life guidance in the Edo period held a consciously preventative orientation that prioritised self-care as a strategy to avoid getting sick in the first place. Medicine and food were often set as oppositional categories, and nourishing life authors deliberately sought to distance the dietary regimens they recommended from 'medication,' even when discussing the prevention of specific diseases. Miyake noted in Japanese Household Secrets that when one properly nourishes one's body "it removes diseases on its own. This is the essential point of healing the not-yet-ill and is an important aspect of nourishing life" (Miyake 1806 [1737]a, 47). ${ }^{10}$ By practicing proper habits and eating right, illness could be stopped before it started.

Ekiken Kaibara and Takeharu Miyake saw a kind of 'violence' (攻撃) in medications, which could damage the stomach and cause the ill to lose their appetite (Kaibara 1972 [1713]; Miyake 1806 [1737]a, 62). Even famed Dutch studies physician Genpaku Sugita [杉田 玄白; 1733-1817] commented on preventative practice versus retroactive treatment in his Seven Wrongs of Nourishing Life [養生七不可; 1801] to recommend that “one should not take medicine when nothing is wrong" (Sugita 1917-18 [1801], 6).

Taking medicine to ease digestion meant that the damage was already done, personal responsibility unfulfilled. "After you have damaged your stomach and taken medicine," Ranzan Takai [高井 蘭山; 1762-1839] mused, “isn't it far too late to nourish your diet?” (Takai 1994 [1805]). These guides reveal a tension between diet, as a preemptive program of health maintenance, and medicine-particularly herbal medications-as a potentially harmful last resort to undo bodily damage accumulated through insufficient self-care. "The fact that people now know that medicine medicates people but do not know that food medicates people," Ranzan continued, "can be said to be [a sign of] the decline of the way of medicine" (Takai 1994 [1805], 23-24). Not only did the diverse authors of dietary guidance distinguish between food as preventative and medicinal treatments as retroactive, they drew into question the fundamental premise that one heals and the other does not.

Diet, for these authors, when managed proactively, was healthy; medication was belated and even dangerous. ${ }^{11}$ As methods for the belated treatment of an illness one had allowed to develop, by contrast, medicine and herbal medication came into increasing friction with the preventative impulse of eating right. In exploring this change, I seek not to minimise the breadth or import of medical knowledge in the Edo period but to eschew a narrative that plots nourishing life on a trajectory toward increasing medical and scientific rationality. Back in the present pandemic context of lingering opposition to precautionary measures-mask wearing and vaccines most of all-looking to Japan's past highlights how the recurrent dichotomy between preventative and curative approaches cannot be understood as simply another vector of contemporary political polarisation, though polarisation certainly contributes. 
Among the politicised debates that consume news cycles and the attention of politicians under COVID, perhaps the most contentious has been the false choice between safeguarding the populace from illness and re-opening the economy. Following uneven rounds of quarantine lockdown, fear of medical disruption to the socio-economic imperatives of work and commerce have driven government responses at the local and national level in the United States and elsewhere. Yet the stubborn persistence of the idea that prioritising health and safety runs counter to demands of the global and national economy obscures a history of balancing individual livelihood and collective economic activity that, in Japan's case, extends back to before the advent of modern public health. Both in acute response to outbreaks of epidemic disease and as a baseline state of health maintenance through dietary practices, an economic conceptualisation of illness and its costs was ever-present in early modern Japanese discourses of health without either succumbing to a zero-sum notion of body versus money. ${ }^{12}$

Early modern Japanese nourishment guidance writers from so many diverse backgrounds and intellectual lineages came to care, think and publish about diet to the degree they did because, from an economic standpoint, a wellnourished body meant a working body, implicating eating habits in maintaining collective stability. Whether intellectual-bureaucratic tasks, agricultural labor, artisanal fabrication or commercial transaction, there was a productive role to fulfill for members of every status group. As historian Katsuya Hirano writes, "the regime's long-term survival depended on the extent to which the body could be successfully conceptualised and mobilised as a productive force" $(2011,507)$. The social architecture of the Tokugawa period was constructed, in part, on the assumption that healthy bodies were capable of fulfilling their prescribed roles-that is, of working. Instead of eating right for the sake of personal well-being, the logic of Tokugawa-era health compelled one to eat in such a way as to keep one's body in good working condition.

Popular writers like Nanboku Mizuno [水野 南北; 1760-1834], a commoner physiognomist dedicated to determining people's fortunes through eating habits, envisioned dietary reform as a force for self-improvement in health, social standing and economic livelihood. For Mizuno, discretion in diet was so powerful that it could overcome fate. "Even if you are destined to be poor," he claimed, "when you are aware of [potential] poverty and strictly arrange for yourself a diet of simple food as if you truly were poor, you can escape and achieve boundless fortune through your own choices. This is called 'making your own fortune."'13 One's personal health decisions, in other words, could dictate whether consumption became an engine of wellbeing or of physical, and by extension socio-economic, degradation.

Characteristic of early modern Japanese dietary guidance more generally, Mizuno's conception of the impact of eating habits on livelihood was not solely focused on personal financial gain. He also understood proper nourishment

12 In the case of epidemic disease response, the economic conceptualisation of bodily health was generative of a variety of representations and meanings in popular culture. See Gramlich-Oka $(2009,32-73)$.

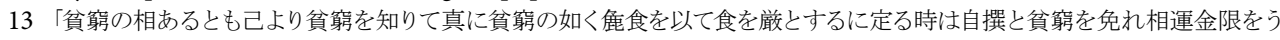
る此を自福じ得といふ。」See Mizuno $(1812,17)$. 
to be fundamentally connected to the material role of the body in the Tokugawa workforce and economy more broadly. In a series of lessons framed as hypothetical question-and-answer sessions with concerned patients, he received the following complaint: "Recently my stomach has been in pain, day and night. I am experiencing great suffering, and I cannot do my job" (Mizuno 1991, 107). At the heart of this imaginary patient's concern is the fear that the pain caused by improper regulation of his digestive health would hinder his performance in the real-world economy.

This connection drawn between the health of the populace and the condition of personal and national economies continued into the early Meiji period, when nourishing life practices remained a topic of popular concern. In his health manual An Encouragement of Nourishing [養生のす〉め; 1876], Yoshiharu Uratani [浦谷 義春; dates unknown] makes the point even more directly:

Nourishing life is the beginning of health, [and] health is the foundation of industriousness and perseverance, good fortune and long life. By first putting their bodies in order and prospering in their professions, people generate assets and serve their ruler and parents in loyalty and filial piety. It is for this reason alone that the results of their industriousness and perseverance, in the long run, benefit the nation. ${ }^{14}$

(Uratani 1876, 4)

By encouraging a healthy, functioning body, dietary guidance aligned individual aspirations for personal and household prosperity with state goals of economic productivity and a willing observation of social roles and rules.

\section{CONCLUSION: TOWARDS TRANSHISTORICAL HEALTH IN JAPAN, POST-PANDEMIC}

Dietary guidance in early modern Japan framed the responsibility for maintaining one's health as part of a collective societal imperative, not as a solely personal decision. My research into the social dynamics of diet in this context reveals how health was neither strictly individualistic nor unconcerned with broader notions of community and economic cohesion. Authors of health guides, and guidance on eating right in particular, conceived of wellnourished bodies in the context of collective social, moral and economic wellbeing. The Meiji-era national mobilisation of healthy bodies was, in part, an extension of these early modern sensibilities about health oriented toward the collective public good, even if not directed by biomedicine or statecraft. Ultimately, these provocations have been a narrative about taking care of oneself for the benefit of the social good-about what the body could become in the world when properly fueled-even if they fall outside of our expected norms of faith in medicine and state-sponsored public hygiene campaigns grounded in modern scientific inquiry.

As this volume seeks an interdisciplinary, border-crossing future for Japanese Studies, this article argues that studies of Japan's past have much to say about the pressing concerns of our global present, if we are willing to ask tough 
questions of ourselves and diversify our definition of borders. Reflecting on the future of Japanese Studies from a health history perspective, the COVID-19 pandemic forces us to rethink not only our future research methods but our very research questions, balancing rich and specific studies of Japanese society with tensions that extend beyond borders, whether national or temporal. No longer can we afford to wall off the past from the present, asking of each only what we presume to be their privileged concerns. Like the eclectic expertise of early modern Japanese medical knowledge or the heterogeneity of its dietary recommendations, we could instead embrace a chronological omnivorousness, never reserving a say in contemporary social problems only for eras and areas that we deem sufficiently recent and, therefore, relevant. Our questions are not new, nor will our answers be without a recognition of the resonances of history.

\section{REFERENCES}

\section{Primary Sources}

Kaibara, E. [貝原 益軒]. 1972 [1713]. Yōjōkun / Wazoku dōjikun [養生訓・和俗童子 訓]. Edited by K. Ishikawa [石川 謙]. Tokyo: Iwanami Shoten [岩波書占].

Miyake, T. [三宅 建治]. 1806 [1737]a. Nihon kyoka hiyō [日本居家秘用], volume 5. Osaka: Jōgakudō [定学堂].

1806 [1737]b. Nihon kyoka hiyō [日本居家秘用], volume 6. Osaka: Jōgakudō [定学堂].

Mizuno, N. [水野 南北]. 1812. Nanboku sōhō gokui bassui [南北相法極意抜萃]. Naniwa [Osaka]: Ōgiya Risuke [扇屋利助].

Sugita, G. [杉田 玄白]. 1917-18 [1801]. Yōjō shichi fuka [養生七不可].Reproduced in Nihon eisei bunko [日本衛生文庫], volume 1. Edited by H. Miyake [三宅 秀] and K. Ōzawa [大沢 謙二]. Tokyo: Kyōiku Shinchō Kenkyūkai [教育新潮研 究会].

Takai, R. [高井 蘭山]. 1994 [1805]. Shokuji kai [食事戒]. Reproduced in Edo jidai josei bunko [江戸時代女性文庫], volume 76. Tokyo: Ōzorasha [大空社].

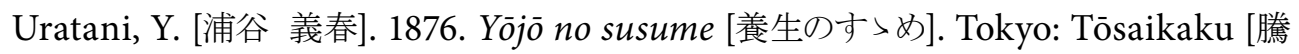
采閣].

\section{Secondary Sources}

Bianchi, A. 2014. "Introduction to Medicine or Satire on Doctors? Approaching the Protean Nature of Isha Dangi." East Asian Publishing and Society 4 (1): 65-114. https://doi.org/10.1163/22106286-12341256.

Biltekoff, C. 2013. Eating Right in America: The Cultural Politics of Food and Health. Durham: Duke University Press. 
Burns, S. 2000. "Constructing the National Body: Public Health and the Nation in Nineteenth-Century Japan." In Nation Work: Asian Elites and National Identities. Edited by T. Brook and A. Schmid. Ann Arbor: University of Michigan Press.

File, T. and A. Mohanty. "Around Half of Unvaccinated Americans Indicate They Will 'Definitely' Get COVID-19 Vaccine." United States Census Bureau. Accessed 18 February, 2021. https://www.census.gov/library/stories/2021/ 01/around-half-of-unvaccinated-americans-indicate-they-will-definitelyget-covid-19-vaccine.html.

Gordon, A. and M. R. Reich. 2021. "The Puzzle of Vaccine Hesitancy in Japan." The Journal of Japanese Studies 47 (2): 411-36. https://doi.org/10.1353/jjs.2021. 0047.

Gramlich-Oka, B. 2009. “The Body Economic: Japan’s Cholera Epidemic of 1858 in Popular Discourse." East Asian Science, Technology, and Medicine 30: 3273. https://doi.org/10.1163/26669323-03001004.

Haberman, M. and M. Crowley. 2020. "Trump Calls Fauci 'A Disaster' and Says Americans are Tired of Virus Warnings from 'These Idiots," New York Times, 19 October. Accessed 18 February, 2021. https://www.nytimes.com/2020/ 10/19/us/elections/trump-fauci.html.

Hirano, K. 2011. "Politics and Poetics of the Body in Early Modern Japan." Modern Intellectual History 8 (3): 499-530. https://doi.org/10.1017/S1479244311000 333.

Jannetta, A. 2009. "Jennerian Vaccination and the Creation of a National Public Health Agenda in Japan, 1850-1900." Bulletin of the History of Medicine 83 (1): 125-140. https://doi.org/10.1353/bhm.0.0185.

2007. The Vaccinators: Smallpox, Medical Knowledge, and the "Opening" of Japan. Stanford: Stanford University Press.

Johnston, W. 1995. The Modern Epidemic: A History of Tuberculosis in Japan. Cambridge: Harvard University Press.

Lynteris, C. 2011. "From Prussia to China: Japanese Colonial Medicine and Gotō Shinpei's Combination of Medical Police and Local Self-Administration." Medical History 55 (3): 343-47.

Mizuno, N. Food Governs Your Destiny: The Teachings of Nanboku Mizuno. Edited and translated by M. Kushi and A. Kushi. New York: Japan Publications, Inc.

Sakai, S. [酒井 シズ]. 2003. E de yomu Edo no yamai to yōjō [絵で読む江戸の病と養 生]. Tokyo: Kōdansha [講談社].

Schlachet, J. 2018. "Nourishing Life: Diet, Body, and Society in Early Modern Japan." $\mathrm{PhD}$ dissertation, Columbia University. 
Steelfisher, G. K., R. J. Blendon and H. Caporello. 2021. "An Uncertain PublicEncouraging Acceptance of Covid-19 Vaccines.” The New England Journal of Medicine 384 (16): 1484-87.

Takizawa, T. [瀧澤 利行]. 1993. “Kindai Nihon kenkō shisō no seiritsu [近代日本健康 思想の成立].” In Kindai Nihon yōjōron, eiseiron shūsei [近代日本養生論・衛生 論集成]. Tokyo: Ōzorasha [大空社].

2003. Yōjōron no shisō [養生論の思想]. Yokohama: Seori Shobō [世織書房].

Trambaiolo, D. 2013. "Native and Foreign in Tokugawa Medicine." The Journal of Japanese Studies 39 (2): 299-324. https://doi.org/10.1353/jjs.2013.0040.

"The Language of Medical Knowledge in Tokugawa Japan." In Rethinking East Asian Languages, Vernaculars, and Literacies, 1000-1919. Edited by B. Elman. Leiden: Brill.

Umihara, R. [海原 亮]. 2014. Edo jidai no ishi shugyō: gakumon, gakutōo, yūgaku [江戸時代の医師修業: 学問・学統・遊学]. Tokyo: Yoshikawa Kōbunkan [吉川 弘文館]. 